\title{
Changes in Body Growth of Labeo rohita in Relation to Dietary Carbohydrate Content and Protein Levels using Gelatinized and Non- Gelatinized Corn
}

\author{
Mahwish Qamer*, Farkhanda Asad and Nimra Tahir \\ Department of Zoology, Wildlife and Fisheries, GC, University Faisalabad, Pakistan
}

\begin{abstract}
For a twelve week experiment, three varying crude protein levels $(30,35$ and $40 \%)$ were considered to observe the growth and meat composition changes in Labeo rohita raised on six semi purified diets (T1: G, 30\% CP; T2: NG, 30\% CP; T3: G, 35\% CP; T4: NG, 35\% CP; T5: G, 40\% CP and T6: NG, 40\% CP) formulated with either gelatinized or nongelatinized corn starch followed by two replicates for each diet. Fish reared on $\mathrm{T} 5$ (G, 40\% CP) exhibited highest average body weight $(3.63 \pm 0.00 \mathrm{~g})$ followed by T3 $(3.51 \pm 0.00 \mathrm{~g})$, T6 $(3.50 \pm 0.00 \mathrm{~g})$, T1 $(3.49 \pm 0.00$ $\mathrm{g})$, T4 $(3.38 \pm 0.00 \mathrm{~g})$ and T2 $(3.36 \pm 0.00 \mathrm{~g})$ respectively. The statistical differences among these diets were nonsignificant. Correspondingly, average total length achieved by fingerlings was capital $(3.30 \pm 0.00 \mathrm{~cm})$ treated on T5 (G, 40\% CP), followed by T3 $(3.28 \pm 0.00 \mathrm{~cm})$, T1 $(3.20 \pm 0.00 \mathrm{~cm})$, T4 $(3.19 \pm 0.00 \mathrm{~cm})$, T6 $(3.16 \pm 0.00 \mathrm{~cm})$ and $\mathrm{T} 2(3.15 \pm 0.00 \mathrm{~cm})$ indicating non-significant differences among diets. Many factors can affect meat quality on the way from producer to consumer. Meat Science is a broad research field where these factors are evaluated in relation to a range of production and quality parameters. Protein, fat and ash content deposition was maximum in fish body meat raised on T5 while dry matter and gross energy retention was highest in T6. Convincingly, it is concluded that gelatinized corn starch at $40 \%$ protein level is promising fish feed ingredient for excellent outcomes of quality of meat and growth excellence.
\end{abstract}

\section{Keywords: Corn; Digestibility; Gelatinized; Labeo rohita}

\section{Introduction}

Pakistan faces multiple and interrelated challenges ranging from the impact of the current economic and financial crisis to a greater vulnerability to climate change and extreme weather events. At the same time, we also have to balance the satisfaction of urgent needs for food and nutrition for a growing population with limited natural resources. Corn is rich source of complex carbohydrates, which are chains of simple sugars consist essentially of starch and fibers that occurs in all plant foods. Energy is supplied 4 calories per gram, as well as proteins and also prevents the organic load in ecosystems that ultimately increase pollution. It has been reported that appropriate levels of fat and carbohydrate sources in fish feed can reduce protein breakdown [1]. Rohu, one of three carp (IMC) and an omnivorous fish, has the ability to use carbohydrates to $43 \%$ in the diet without adverse health effects [2]. This study aimed to determine the effect of corn on meat quality being main source of carbohydrates and make a comparison of important aspects of growth performance of $L$. rohita fed corn feed (G/NG) at three protein levels i.e. 30\%, 35\% and $40 \%$ in practical and economic systems for commercially available species of carp. These new formulations can minimize the cost of fish and improve the growth and body profile regarding composition and quality of meat.

In fish farming nutrition is critical because feed represent $40-50 \%$ of production costs. The general problem of high feed cost associated with fish culture has been addressed by studies on the use of cheaper ingredients as protein sources. Another approach to reduce feed cost is to develop appropriate feeding management strategies and other improvements in husbandry [1]. Keeping in view the economic importance of fish feeding, present study was carried out to determine the growth response of Labeo rohita fingerlings fed with different feeding regimes under intensive rearing.

\section{Materials and Methods}

\section{Experimental diets}

The basic feed ingredient i.e. corn was procured and ground to make powder which were added approximately $80 \%$ of water $(\mathrm{v} / \mathrm{w})$ and autoclaved at 15 psi for one hour to obtain maximum gelatinization. These gelatinized corn ingredients were spread over a tray and dried in

\begin{tabular}{|l|c|c|c|}
\hline Ingredient & $\mathbf{3 0 \%} \mathbf{C P}$ & $\mathbf{3 5 \%} \mathbf{C P}$ & $\mathbf{4 0 \%} \mathbf{C P}$ \\
\hline Casein \% & 26.57 & 30.57 & 35.2 \\
\hline Gelatin \% & 4 & 8 & 5 \\
\hline Corn\%G/NG & 42.43 & 42.43 & 42.4 \\
\hline Cellulose \% & 15 & 7 & 7.4 \\
\hline Sunflower: Codliveroil (2:1)\% & 8 & 8 & 6 \\
\hline Carboxymethyl cellulose \% & 1 & 1 & 1 \\
\hline Vitamin+mineral mix \% & 2.6 & 2.6 & 2.6 \\
\hline Vitamin C \% & 0.1 & 0.1 & 0.1 \\
\hline Vitamin B \% & 0.1 & 0.1 & 0.1 \\
\hline Glycine \% & 0.2 & 0.2 & 0.2 \\
\hline BHT \% & 0.2 & 0.2 & 0.2 \\
\hline
\end{tabular}

(*the antioxidant ButylatedHydroxy Toluene was added at $0.02 \%$ of the added oil) Table 1: Percentage composition of test diets.

*Corresponding author: Mahwish Qamer, Department of Zoology, Wildlife and Fisheries, GC, University Faisalabad, Pakistan, Tel: 92-333-8618057; E-mail: mahwishqamer@gmail.com

Received April 17, 2014; Accepted July 21, 2014; Published July 31, 2014

Citation: Qamer M, Asad F, Tahir N (2014) Changes in Body Growth of Labeo rohita in Relation to Dietary Carbohydrate Content and Protein Levels using Gelatinized and Non-Gelatinized Corn. J Aquac Res Development 5: 248 doi:10.4172/21559546.1000248

Copyright: $\odot 2014$ Qamer M, et al. This is an open-access article distributed under the terms of the Creative Commons Attribution License, which permits unrestricted use, distribution, and reproduction in any medium, provided the original author and source are credited. 
Citation: Qamer M, Asad F, Tahir N (2014) Changes in Body Growth of Labeo rohita in Relation to Dietary Carbohydrate Content and Protein Levels using Gelatinized and Non-Gelatinized Corn. J Aquac Res Development 5: 248 doi:10.4172/2155-9546.1000248

oven at $60^{\circ} \mathrm{C}$. The dried mass was then pulverized through a hammer mill with $0.5 \mathrm{~mm}$ screen. Protein source was gelatin and fat free casein, while lipid source was sunflower oil and cod liver oil and carbohydrate source was corn (G or NG). All these ingredients (Table 1) were ground and sieved to incorporate into diets and mixed well for 30 minutes, then fish oil was slowly added, while mixing thoroughly. Then the dough was given steam for $5 \mathrm{~min}$ in an autoclave. Vitamin-mineral premix was added after cooling the dough and then pellets of $2 \mathrm{~mm}$ were made by hand pelletizer. The pellets were dried in a drying oven for 48 hours and stored until use. Three different crude protein levels (30\%, 35\% and $40 \%$ ) were used to formulate six semi purified diets (T1: G, $30 \% \mathrm{CP}$; T2: NG, 30\% CP; T3: G, 35\% CP; T4: NG, 35\% CP; T5: G, 40\% CP and T6: NG, 40\% CP) with either gelatinized or non-gelatinized cornstarch.

\section{Experimental design and feeding protocol}

Labeo rohita fingerlings purchased from government fish seed hatchery, Satiana road, Faisalabad were allowed to acclimate at ambient conditions fed on control diet (NG, 30\% CP) for one week before initiating the trial. After acclimatization, fingerlings were transferred randomly into glass aquaria $[90 \mathrm{~L} \times 30 \mathrm{~W} \times 45 \mathrm{H}(\mathrm{cm})$ with $29 \mathrm{~L}$ water capacities each]. For each treatment there were two replicates and in each replica forty fingerlings were stocked. Fish were given test diets at the rate of $4 \%$ live wet body weight twice a day (morning and afternoon) in the feeding aquarium.

\section{Growth studies}

The morphometric characteristics i.e. body length $(\mathrm{cm})$ and body weight (g) of fingerlings taken from each replicate on express sampling time as day basis were measured and recorded. After obtaining the data, the fishes were released back into their respective aquaria.

\section{Meat quality analysis}

At the end of the experiment, representative samples of fish body meat from each replica were homogenized individually using a mortar pestle and analyzed chemically by $\mathrm{AOAC}$ procedures: dry matter (DM) by oven drying at $105^{\circ} \mathrm{C}$; crude protein (CP) by microkjeldahl analysis, crude fat by chloroform methanol extraction method through 10454 soxtec system HTz, crude fiber by ash-free residue digested with alkali and acid, ash through electric furnace. After finding the possible results, data of growth and body composition was subjected to analysis of variance (ANOVA), SPSS for statistical analysis and mean \pm SE values were calculated.

\section{Determination of meat quality}

Most reindeer producers in Alaska use an extensive management system where animals are allowed to free-range over large designated grazing ranges on the Seward Peninsula, St Lawrence and Nunivak
Islands and the Aleutian Chain. These ranges are large and remote with no or limited availability of slaughtering, processing and transportation infrastructure. Some reindeer producers want to shift the management and location of their operations to more intensively managed farms in Interior Alaska to utilize cereal grain and forage production, slaughtering facilities, and transportation and distribution networks. Currently voluntary state inspection is utilized for reindeer field-slaughter but a federal inspection program is in the process of being initiated. Therefore it is anticipated that more meat from Alaska's reindeer herd will be marketed to consumers and restaurants where questions about meat quality and sensory attributes will arise.

\section{Results}

\section{Growth}

Values of average increase in body weights of fish fed on three diets are given in Figure 1. At the termination of experiment, fish reared on T5 (G, 40\% CP) showed the highest final average body weight ( $3.63 \mathrm{~g})$ with the initial average body weight $(2.68 \mathrm{~g})$ as compared to the other diets. The maximum and minimum gain in

body weight of Labeo rohita in test T5 (G, 40\% CP) was recorded $(0.19 \mathrm{~g})$ and $(0.01 \mathrm{~g})$ during $7^{\text {th }}$ express sampling time as day (April) and $1^{\text {st }}$ express sampling time as day (January) followed by T3 (3.51 \pm $0.00 \mathrm{~g}), \mathrm{T} 6(3.50 \pm 0.00 \mathrm{~g}), \mathrm{T} 1(3.49 \pm 0.00 \mathrm{~g}), \mathrm{T} 4(3.38 \pm 0.00 \mathrm{~g})$ and T2 $(3.36 \pm 0.00 \mathrm{~g})$ respectively. Values for average total length and gain in total length of rohu for all diets

are in Table 2 and in Figure 2. Average total length achieved by fingerlings was capital $(3.30 \pm 0.00 \mathrm{~cm})$ treated on T5 followed by T3 $(3.28 \pm 0.00 \mathrm{~cm}), \mathrm{T} 1(3.20 \pm 0.00 \mathrm{~cm}), \mathrm{T} 4(3.19 \pm 0.00 \mathrm{~cm}), \mathrm{T} 6(3.16 \pm$ $0.00 \mathrm{~cm})$ and $\mathrm{T} 2(3.15 \pm 0.00 \mathrm{~cm})$.

\section{Meat quality}

The results obtained after body meat analysis of rohu (Table 3 ) and its body composition compared under all diets is shown in Figures 3-7. The result of this analysis showed that all diets and their interaction have pronounced effect on body of fish. The dry matter (\%) deposition was found maximum (Figure 3) in fish body meat reared on T6: NG, $40 \%$ CP (98.89\%) and minimum in fish body meat reared on T1: G, $30 \%$ CP (96.00\%). The retention of ash content (\%) was found maximum (Figure 4) in fish body meat reared on T5: G, 40\% CP (87.59\%) and minimum in fish body meat reared on T4: NG, 35\% CP (82.50\%). The crude fat (\%) deposition was found maximum (Figure 5) in fish body meat reared on T5: G, $40 \% \mathrm{CP}$ as $38 \%$ and minimum in fish body meat reared on T2: NG, 30\% CP (22\%). Crude protein (\%) retention was found maximum (Figure 6) in fish body meat reared on T5: G, 40\% CP as $39.02 \%$ and minimum in fish body meat reared on $\mathrm{T} 2$ : NG, $30 \% \mathrm{CP}$ (31.23\%). Gross energy (\%) retention was found maximum (Figure 7)

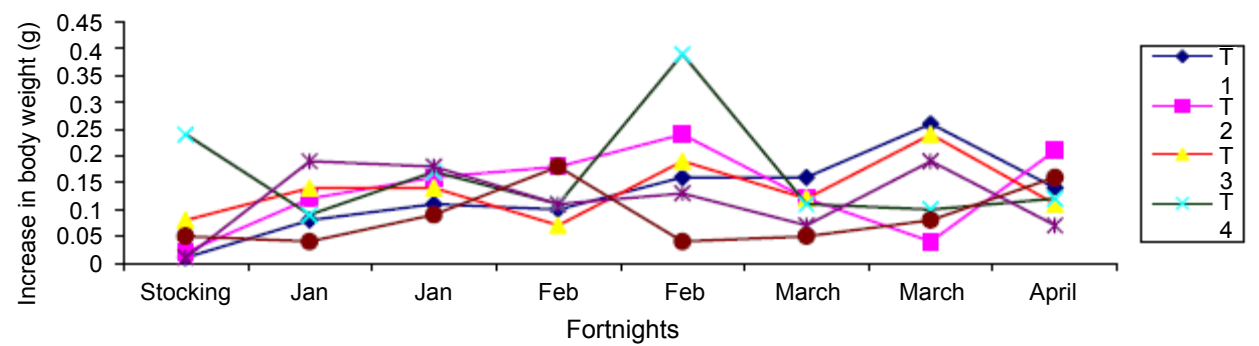

Figure 1: Increase in body weight of Labeo rohita reared under different test diets (G/NG) on express sampling time as day basis. 
Citation: Qamer M, Asad F, Tahir N (2014) Changes in Body Growth of Labeo rohita in Relation to Dietary Carbohydrate Content and Protein Levels using Gelatinized and Non-Gelatinized Corn. J Aquac Res Development 5: 248 doi:10.4172/2155-9546.1000248

Page 3 of 4

\begin{tabular}{|c|c|c|c|c|c|c|c|c|c|c|c|c|c|}
\hline \multirow[b]{2}{*}{$\begin{array}{l}\text { Express sampling } \\
\text { time as day }\end{array}$} & \multirow[b]{2}{*}{$\begin{array}{c}\text { Date of } \\
\text { observation }\end{array}$} & \multicolumn{2}{|c|}{ T1 } & \multicolumn{2}{|c|}{ T2 } & \multicolumn{2}{|c|}{ T3 } & \multicolumn{2}{|c|}{ T4 } & \multicolumn{2}{|c|}{ T5 } & \multicolumn{2}{|c|}{ T6 } \\
\hline & & $\begin{array}{c}\text { Average } \\
\text { body } \\
\text { length } \\
\text { (cm) }\end{array}$ & $\begin{array}{l}\text { Increase } \\
\text { in body } \\
\text { length } \\
\text { (cm) }\end{array}$ & $\begin{array}{c}\text { Average } \\
\text { body } \\
\text { length } \\
\text { (cm) }\end{array}$ & $\begin{array}{l}\text { Increase } \\
\text { in body } \\
\text { length } \\
\text { (cm) }\end{array}$ & $\begin{array}{c}\text { Average } \\
\text { body } \\
\text { length } \\
\text { (cm) }\end{array}$ & $\begin{array}{l}\text { Increase } \\
\text { in body } \\
\text { length } \\
\text { (cm) }\end{array}$ & $\begin{array}{c}\text { Average } \\
\text { body } \\
\text { length } \\
\text { (cm) }\end{array}$ & $\begin{array}{l}\text { Increase } \\
\text { in body } \\
\text { length } \\
\text { (cm) }\end{array}$ & $\begin{array}{c}\text { Average } \\
\text { body } \\
\text { length } \\
\text { (cm) }\end{array}$ & $\begin{array}{c}\text { Increase } \\
\text { in body } \\
\text { length } \\
(\mathrm{cm})\end{array}$ & $\begin{array}{c}\text { Average } \\
\text { body } \\
\text { length } \\
\text { (cm) }\end{array}$ & $\begin{array}{l}\text { Increase } \\
\text { in body } \\
\text { length } \\
\text { (cm) }\end{array}$ \\
\hline Stocking & $11 / 120012$ & 1.75 & & 1.85 & & 2.05 & & 2.2 & & 2.16 & & 1.9 & \\
\hline 1 & 4/1)2013 & 1.9 & 0.15 & 1.99 & 0.14 & 1.21 & 0.16 & 2.27 & 0.07 & 2.26 & 0.1 & 2.15 & 0.25 \\
\hline 2 & 18/1/2013 & 2.05 & 0.15 & 2.16 & 0.17 & 2.35 & 0.14 & 2.36 & 0.09 & 2.42 & 0.16 & 2.26 & 0.11 \\
\hline 3 & 7/2/2013 & 2.3 & 0.25 & 2.27 & 0.11 & 2.53 & 0.18 & 2.44 & 0.08 & 2.63 & 0.21 & 2.47 & 0.21 \\
\hline 4 & 11/1/2013 & 2.51 & 0.11 & 2.35 & 0.08 & 2.78 & 0.25 & 2.6 & 0.16 & 2.85 & 0.22 & 2.6 & 0.13 \\
\hline 5 & $8 / 7 / 2013$ & 2.75 & 0.24 & 2.44 & 0.09 & 2.97 & 0.19 & 2.71 & 0.11 & 2.95 & 0.1 & 1.72 & 0.12 \\
\hline 6 & $2 / 31 / 2013$ & 3.05 & 0.3 & 2.82 & 0.38 & 3.08 & 0.11 & 2.86 & 0.15 & 3.09 & 0.14 & 2.9 & 0.18 \\
\hline 7 & $5 / 4 / 2013$ & 3.16 & 0.11 & 3.01 & 0.19 & 3.2 & 0.12 & 2.99 & 0.13 & 3.19 & 0.1 & 3 & 0.1 \\
\hline 8 & $15 / 4 / 2013$ & 3.2 & 0.04 & 3.15 & 0.14 & 3.28 & 0.08 & 3.19 & 0.2 & 3.3 & 0.11 & 3.16 & 0.16 \\
\hline $\begin{array}{l}\text { Total increase in } \\
\text { length }\end{array}$ & & & 1.45 & & 1.3 & & 1.23 & & 0.99 & & 1.14 & & 1.26 \\
\hline
\end{tabular}

Table 2: Express sampling time as daily increase in average total body length $(\mathrm{cm})$ of Labeo rohita reared under different test diets (G/NG).

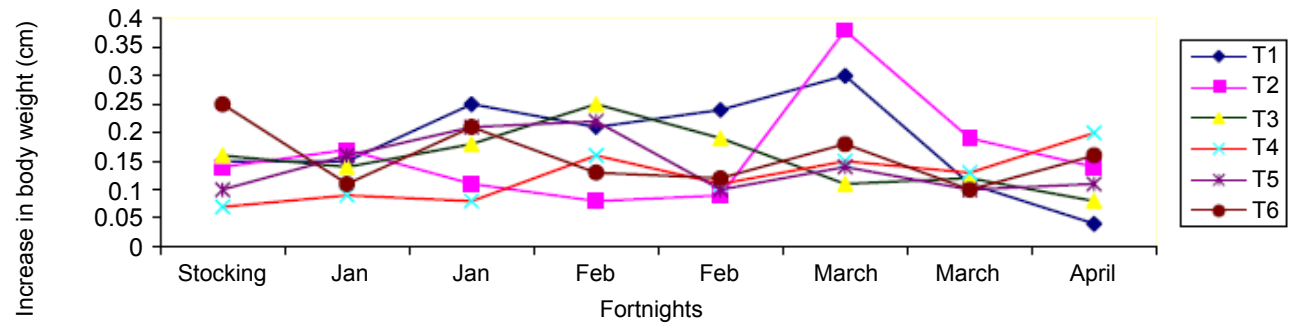

Figure 2: Increase in body length of Labeo rohita reared under different test diets $(\mathrm{G} / \mathrm{NG})$ on express sampling time as day basis.

\begin{tabular}{|l|l|l|}
\hline Treatment & Body weight & Body length \\
\hline T1 $(30 \mathrm{G})$ & $2.87 \pm 0.53 \mathrm{~A}$ & $2.52 \pm 0.54 \mathrm{~A}$ \\
\hline T2 $(30 \mathrm{NG})$ & $2.77 \pm 0.53 \mathrm{~A}$ & $2.49 \pm 0.52 \mathrm{~A}$ \\
\hline T3 $(35 \mathrm{G})$ & $2.92 \pm 0.55 \mathrm{~A}$ & $2.72 \pm 0.53 \mathrm{~A}$ \\
\hline T4 $(35 \mathrm{NG})$ & $2.75 \pm 0.55 \mathrm{~A}$ & $2.63 \pm 0.50 \mathrm{~A}$ \\
\hline T5 $(40 \mathrm{G})$ & $3.15 \pm 0.57 \mathrm{~A}$ & $2.76 \pm 0.53 \mathrm{~A}$ \\
\hline T6 $(40 \mathrm{NG})$ & $3.12 \pm 0.56 \mathrm{~B}$ & $2.57 \pm 0.52 \mathrm{~B}$ \\
\hline
\end{tabular}

Table 3: Comparison of means of body weight and total length of Labeo rohita reared under different test diets $(\mathrm{G} / \mathrm{NG})$.

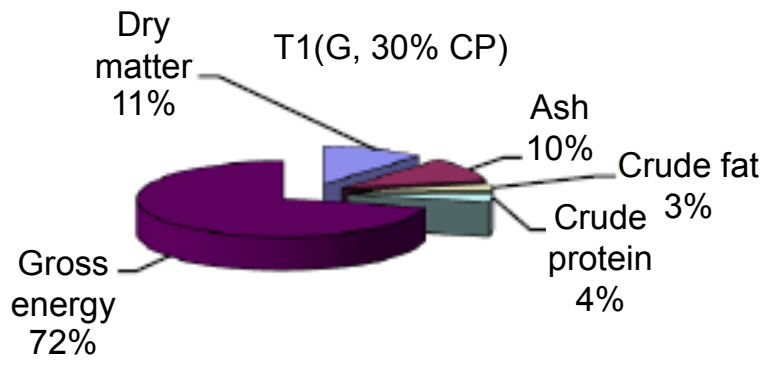

Figure 3: Percentage body composition of fish meat of Labeo rohita reared under $\mathrm{T} 1(\mathrm{G}, 30 \% \mathrm{CP})$.

in fish body meat reared on T6: NG, 40\% CP (649.20\%) and minimum in fish body meat reared on T2: NG, 30\% CP (597.80\%) (Table 4). Conclusively protein, fat and ash content deposition was maximum in fish body meat raised on T5 while dry matter and gross energy retention was highest in T6 (Figure 8).
T3 (G, 35\% CP)

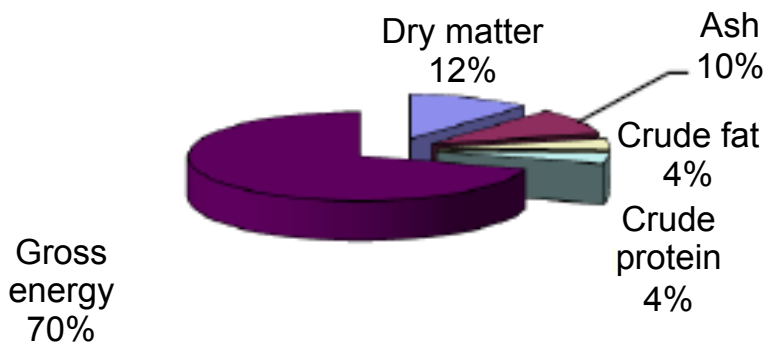

Figure 4: Percentage body composition of fish meat of Labeo rohita reared under T3 (G, 35\%CP).

T2 (NG, 30\% CP)

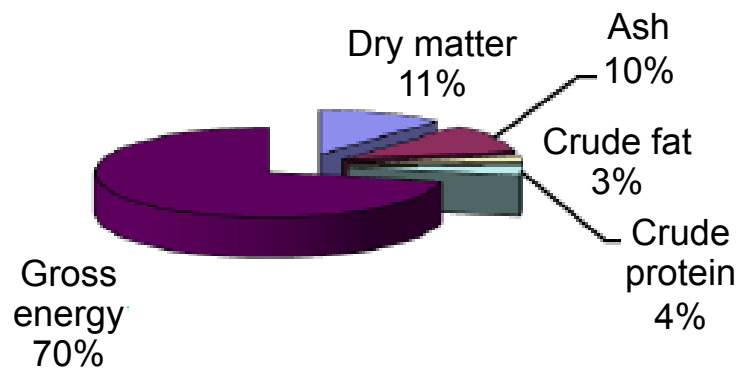

Figure 5: Percentage body composition of fish meat of Labeo rohita reared under T2 (NG, 30\%CP). 
Citation: Qamer M, Asad F, Tahir N (2014) Changes in Body Growth of Labeo rohita in Relation to Dietary Carbohydrate Content and Protein Levels using Gelatinized and Non-Gelatinized Corn. J Aquac Res Development 5: 248 doi:10.4172/2155-9546.1000248

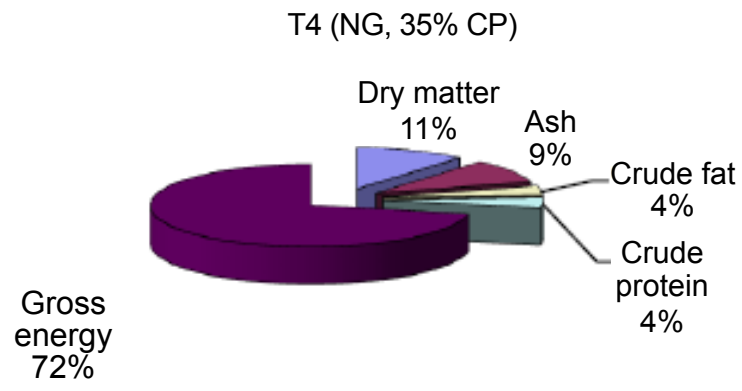

Figure 6: Percentage body composition of fish meat of Labeo rohita reared under T4 (NG, 35\%CP).

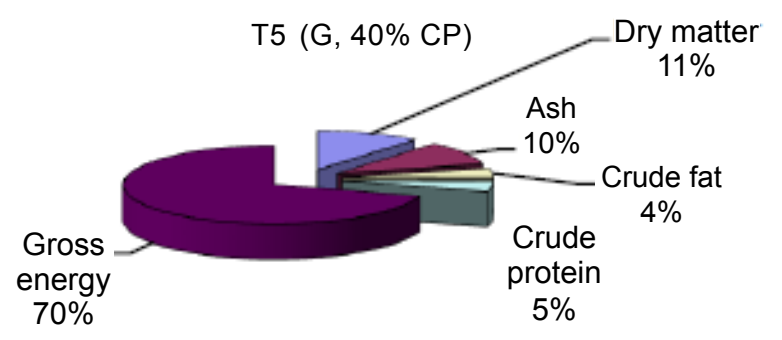

Figure 7: Percentage body composition of fish meat of Labeo rohita reared under T5 (G, 40\%CP).

\begin{tabular}{|c|c|c|}
\hline Express sampling time as days & Body weight & Body length \\
\hline Stocking & $2.49 \pm 0.58 \mathrm{~A}$ & $1.99 \pm 0.54 \mathrm{~A}$ \\
\hline 1 & $2.52 \pm 0.58 \mathrm{~A}$ & $2.13 \pm 0.56 \mathrm{~A}$ \\
\hline 2 & $2.63 \pm 0.58 \mathrm{~A}$ & $2.27 \pm 0.58 \mathrm{~A}$ \\
\hline 3 & $2.77 \pm 0.62 \mathrm{~A}$ & $2.44 \pm 0.58 \mathrm{~A}$ \\
\hline 4 & $2.90 \pm 0.65 \mathrm{~A}$ & $2.62 \pm 0.58 \mathrm{AB}$ \\
\hline 5 & $3.09 \pm 0.69 \mathrm{~B}$ & $2.76 \pm 0.58 \mathrm{~B}$ \\
\hline 6 & $3.20 \pm 0.70 \mathrm{~B}$ & $2.97 \pm 0.68 \mathrm{~B}$ \\
\hline 7 & $3.34 \pm 0.70 \mathrm{~B}$ & $3.09 \pm 0.70 \mathrm{~B}$ \\
\hline 8 & $3.48 \pm 0.70 \mathrm{C}$ & $3.21 \pm 0.70 \mathrm{C}$ \\
\hline
\end{tabular}

Table 4: Means sharing similar letter in a column are statistically non-significant $(P>0.05)$.

T6 (NG, 40\% CP)

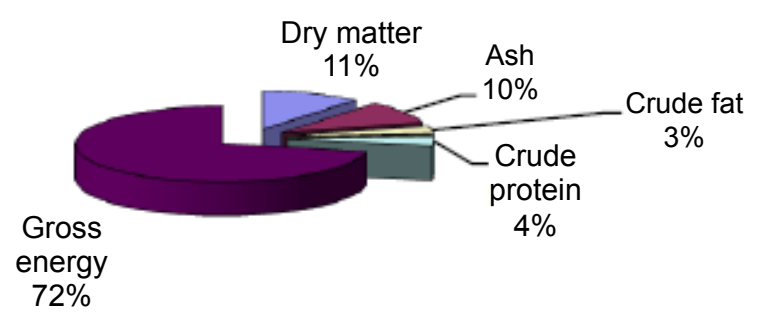

Figure 8: Percentage body composition of fish meat of Labeo rohita reared under T6 (NG, 40\%CP).

\section{Discussion}

At the termination of experiment, fish reared on T5 (G, 40\% CP) showed the highest final average body weight which is in agreement with Yengkokpam [3] that 40\% CP level improves the growth of fish. Greater the level of gelatinization of corn, higher the level of growth observed in Indian major carps [1]. On contrary, higher level of gelatinization has negative influence on growth of Labeo rohita [2].

Comparison of means of body weight and total length of Labeo rohita on express sampling time as day basis and among treatments showed nonsignificant variations among them as reported by Mohapatra [4]. Protein, fat and ash content deposition was found maximum in fish body meat raised on $\mathrm{T} 5(\mathrm{G}, 40 \% \mathrm{CP})$ while dry matter and gross energy retention was highest in T6 (NG, $40 \% \mathrm{CP}$ ) which indicated the protein level in fish feed has pronounced effects on meat profile. On contrary, dietary protein level has no effect on fish body meat [5]. Gelatinization of feed has significant effect on fat and protein deposition in fish body meat at varying protein levels [6,7] which favors the present results.

\section{References}

1. Singh RK, Balange AK, Ghughuskar MM (2006) Protein sparing effect of carbohydrates in the diet of Cirrhinus mrigala (Hamilton, 1822) fry. Aquaculture 258: $680-684$

2. Kumar V, Sahu NP, Pal AK, Kumar S, Gupta SK (2007) Gelatinized to nongelatinized starch ratio in the diet of Labeo rohita: effect on digestive and metabolic response and on growth. Journal of Animal Physiology and Animal Nutrition 92: 492-501.

3. Yengkokpam S, Sahu NP, Pal AK, Mukherjee SC, Debnath D (2007) Gelatinized carbohydrates in the diet of Catla catla fingerlings: Effect of levels and sources on nutrition utilization, body composition and tissue enzyme activities. Journal of Animal Science 2: 89-99.

4. Mohapatra M, Sahu NP, Chaudhari A (2002) Utilization of gelatinized carbohydrate in diets of Labeo rohita fry. Aquaculture nutrition 9: 189-196.

5. Khattab YAE, Ahmed MH, Shalaby AME, Abdel-Tawwab M (2003) Response of Nile Tilapia from different locations to different dietary protein levels. Egypt Aquatic Biology and Fisheries 4: 295-311.

6. Hutchins CG, Rawles SD, Gatlin DM (2011) Effects of dietary carbohydrate kind and level on growth, body composition and glycemic response of juviniles sunshine bass. Aquaculture 161: 187-199.

7. Association of Official Analytical Chemists (1990) Official Methods of Analysis, $15^{\text {th }}$ edn, Association of Official Analytical chemists, Washington DC, USA. 